\title{
REKAYASA LED IKAN MELALUI PENGATURAN LUMENSI CAHAYA BERBASIS PERANGKAT LUNAK VERSI BETHA
}

\author{
ARRANGEMENT OF LED LUMEN BASED ON PULSE WIDTH MODULATION (PWM) \\ BETHA VERSION TO ATTRACT THE SCHOOLING FISH
}

\author{
Agus Cahyadi ${ }^{1)}$ dan Wong Xing You ${ }^{2)}$ \\ ${ }^{1)}$ Pusat Penelitian dan Pengembangan Perikanan \\ ${ }^{2)}$ Electrical Engineering Department, Anhui University, Republic of China \\ e-mail : acahtekla@gmail.com, wongxingyou@667.com
}

Diterima tanggal: 12 Desember 2016, diterima setelah perbaikan: 21 Januari 2017, disetujui tanggal: 23 Januari 2017

\begin{abstract}
ABSTRAK
Beberapa jenis ikan mempunyai fototaksis positif terhadap cahaya berkorelasi terhadap kemampuan histologi ikan untuk mengenal karakteristik spektral. Karakteristik spektral dipengaruhi oleh faktor warna, gelap-terang dan faktor lainnya. Light emitting diode atau LED adalah sirkuit semikonduktor mampu memancarkan cahaya saat dialiri listrik. LED memancarkan cahaya lewat aliran listrik yang relatif tidak menghasilkan banyak panas. Lampu LED terasa dingin dipakai karena tidak menambah panas ruangan seperti lampu pijar berbahan logam halida. Rekayasa LED untuk menarik sekumpulan ikan dirancang sirkuit elektronik dengan menggunakan kombinasi LED dengan variasi panjang gelombang yaitu LED putih (600 nm), biru (465-500 nm), hijau (500$520 \mathrm{~nm}$ ) dan amber (595-605 nm). Melalui pengaturan lumensi LED dengan perangkat lunak menghasilkan pola tertentu untuk mengumpulkan ikan pada malam hari. Pola zig-zag dengan variasi pengulangan mampu menarik perhatian ikan teri jenis Stolephorus sp. untuk mendekati batas lumensi LED ikan selama 3 jam berenang di sekitar alat tersebut.
\end{abstract}

Kata kunci : karakteristik spektral, LED, perangkat lunak, ikan

\begin{abstract}
Several fishes have positive phototaxis to the light to be correlated with histological ability to recoqnize spectral characteristics. The spectral characteristics are influenced by color, brightness and other factors. Light emitting diode or LED is semiconductor circuit being e able to lighting when connected to power supply. LED does not produce heat.. LED engineering to attract the fishes as artificial attractor is by designing a circuit system integrating four LEDs having various spectral waves, i.e. $r$ white $600 \mathrm{~nm}$, blue 465-500 nm, green 500-520 nm and amber 595-605 nm. By controlling LED lumens using a set of software, a certain pattern to attract the fishes in the night is produced. The zigzag pattern is able to attract the small fishes like Stolephorus sp. swimming approximately around LED lumen boundary for 3 hours.
\end{abstract}

Keywords : spectral characteristic, LED, software, fish

\section{PENDAHULUAN}

Penggunaan lampu konvensional seperti strongkeng maupun petromak untuk menarik perhatian ikan mempunyai beberapa kekurangan di antaranya : cahaya yang dihasilkan dari lampu konvensional seperti lampu petromak maupun strongkeng mempunyai kekuatan terang yang dapat menimbulkan masalah serius, dapat menimbulkan bahaya kebakaran di atas kapal apabila cahaya lampu yang dipergunakannya menggunakan bahan bakar, masa pemakaiannya biasanya kurang dari 15 bulan, dan umumnya penggunaan lampu berbahan logam halide memiliki efesiensi yang rendah dan borosnya pemakaian bahan bakar (Yami, 1988). 
Konsekuensinya energi listrik dikonversi menjadi energi panas dan untuk digunakan kembali membutuhkan waktu 10-20 menit. Menurut Najamuddin (1993) bahwa cahaya lampu berbahan logam halide menimbulkan radiasi sinar ultraviolet dan sinar infra merah yang mempengaruhi pertumbuhan juvenile anak ikan pelagis yang tertarik dengan kumpulan zooplankton sebagai makanan. Kenaikan harga bahan bakar minyak (BBM) dalam beberapa tahun terakhir meningkat tajam terlebih penggunaan BBM pada kapal ikan. Kenaikan harga BBM berimbas pada penggunaan lampu sebagai alat penarik ikan dengan kebutuhan BBM yang tidak sedikit. Tingginya intensitas lampu mempunyai hubungan liner terhadap kebutuhan BBM. Efektivitas pancaran lampu yang tidak omnidireksional atau membentuk $360^{\circ}$, mempengaruhi kedatangan ikan mendekati cahaya lampu berkisar $25 \%$ dari total pancaran cahaya lampu yang dioperasikan di atas kapal (Notanubun, 2010).

Menurut Guttsait (2007) bahwa gelap dan terang atau brightness lampu konvensional hanya bisa dilakukan dengan cara mengatur bukaan lampu yang disorotkan pada kumpulan ikan. Dengan demikian saat bukaan cahaya lampu tidak maksimal, konsekuensinya timbulnya cahaya redup disekitar kapal atau bagan ikan hingga berakibat ikan meloloskan diri. Pada spektrum cahaya tampak beberapa ikan ada yang menyukai cahayanya maupun tidak menyukai sama sekali (Guttsait, 2007). Tidak sama pancaran cahaya lampu di udara dengan pancaran cahaya lampu di air laut yang mempengaruhi terang gelap, warna cahaya dsb. Menurut Muhaimin (2001) bahwa sistem pewarnaan cahaya lampu pada Red Green Blue (RGB) pada cahaya lampu LED sangat kompleks dan membutuhkan pengaturan cahaya LED agar tidak gagal.

Untuk mengatasi kendala di atas, invensinya dikhususkan untuk mempengaruhi :

1. Ikan yang mempunyai kemampuan fototaksis

2. Relung ikan hidup pada perbedaan kolom air dengan sensivitas spektral yang berbeda pula.

Oleh karena itu spectral cahaya ikan didasarkan pada karakteristik fisiologis ikan. Cahaya yang menembus air menghasilkan spektrum tertentu dan semakin dalam perairannya spektrumnya pun berubah (Jeff, 2004). Cahaya terang akan terserap dengan adanya perbedaan kolom air. Pengaruh arus laut dan keterbatasan teknologi hanya bisa diusahakan penangkapan ikan pada batasan kedalaman 0 sampai $1000 \mathrm{~m}$ atau bahkan kurang, dan karakteristik spektralnya pun pada rentang 400-750 nm (Jeff, D. 2003).

Plankton merupakan sumber makanan dalam rantai makanan ikan yang hidupnya di permukaan laut dengan kisaran karakteristik spektrum 550-750 nm (Guttsait, 2007). Menurut Baskoro dkk. (2004) bahwa arus permukaan ber-pengaruh terhadap transportasi juvenil sehingga mempengaruhi migrasi ikan ke lokasi penangkapan. Selanjutnya menurut (Najamuddin, 2001) bahwa ikan bereaksi secara langsung terhadap perubahan lingkungan yang dipengaruhi oleh arus dengan menga-rahkan dirinya secara langsung pada arus dan umumnya gerakan ikan selalu menga-rah menuju arus. Tingginya biaya operasional dalam usaha penangkapan ikan merupakan kendala bagi nelayan. Penggunaan sejumlah lampu untuk menarik perhatian ikan berbahan logam halide berdampak merupakan salah satu faktornya. Selama ini pengembangan teknologi lampu untuk menarik perhatian ikan pelagis mendekati sumber cahaya masih terus berkembang. Rancangan light emitting diode ikan dirancang dengan tujuan untuk mengumpulkan sekumpulan ikan melalui pengaturan gelap dan terang (birghtness) berbasis perangkat lunak.

\section{BAHAN DAN METODE}

\begin{abstract}
Waktu
Waktu penelitian dibagi berdasarkan 3 tahapan, yaitu tahapan perancangan perangkat keras, perancangan perangkat lunak dan tahapan pengujian LED ikan. Waktu perancangan perangkat keras dimulai bulan April-Juni 2013 dan waktu perancangan perangkat lunak dimulai bulan Mei-Juli 2013. Untuk pengujian LED ikan yang dilaksanakan pada bulan Agustus-September 2013 yang ditentukan waktunya dari pukul 20.00-24.00 WIT bersamaan dengan dioperasikannya bagan apung yang berlokasi di Kabupaten Wakatobi, Provinsi Sulawesi Tenggara.
\end{abstract}

\section{Bahan}

Perancangan LED ikan menggunakan assembly sirkuit terpadu yang terintegrasi dengan mikrokontroler jenis STEVAL-ILL009V1 (Gambar 1). Pada tahapan ini meliputi tata letak 
komponen, perakitan, pembuatan $\mathrm{PCB}$ dan penyolderan komponen. Pada tahapan pembuatan perangkat lunak dirancang sebuah program yang akan diinputkan, pada mikrokontroler untuk mengolah hasil sinyal dengan menggunakan bahasa pemrograman C (Jeff, 1992). Pengujian perancangan LED ikan pada masing-masing blok digram keseluruhan sistem (Gambar 2).
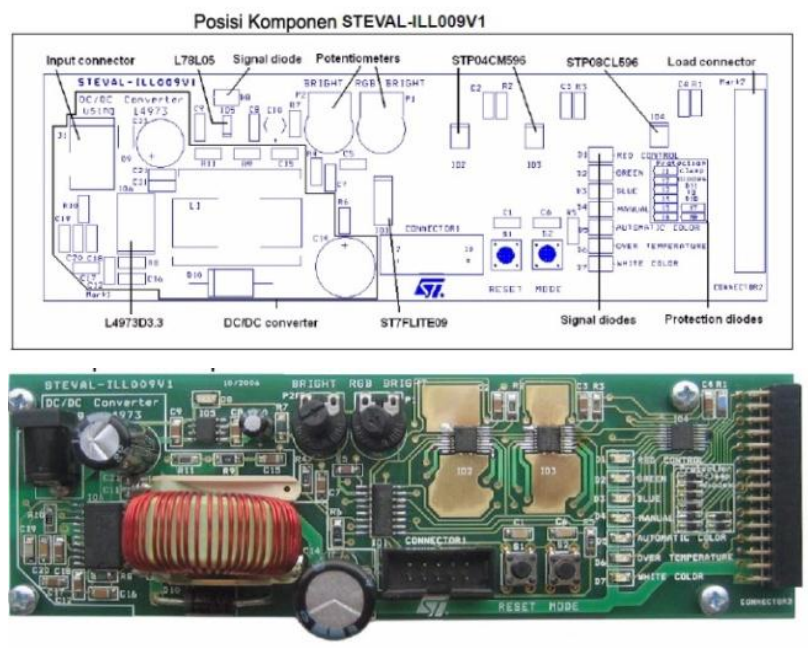

Gambar 1. Sirkuit terintegrasi model STEVAL-ILL0091

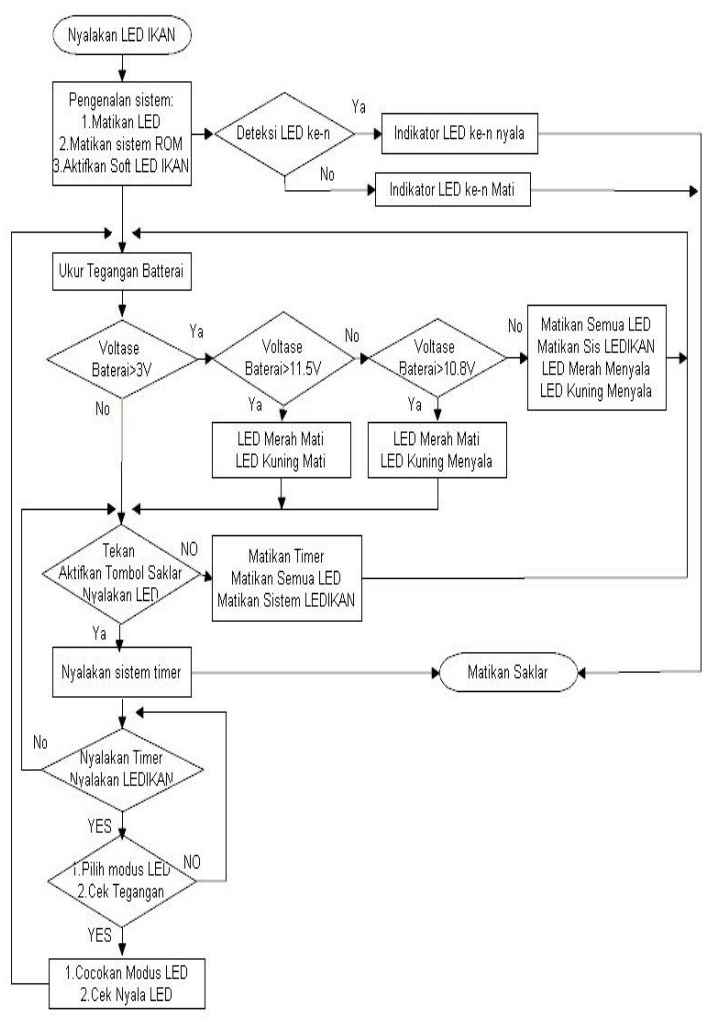

Gambar 2. Digram Blok Perangkat lunak LED Ikan
Input data PWM

Menurut Nasution (2010) pengertian Pulse Width Modulation (PWM) secara umum adalah sebuah cara memanipulasi lebar sinyal yang dinyatakan dengan pulsa dalam suatu perioda, untuk mendapatkan tegangan rata-rata yang berbeda. Dengan cara mengatur lebar pulsa "on" dan "off" dalam satu perioda gelombang melalui pemberian besar sinyal referensi output dari suatu PWM akan didapat duty cycle yang diinginkan. Duty cycle dari PWM dapat dinyatakan formula sebagai berikut (Usman, 2010) :

$$
\begin{aligned}
& B 1=c \cdot \log (i) \\
& B 2=c \cdot \log \left(\frac{i}{3}\right) \\
& \frac{B 2}{B 1}=1-c \cdot \log (3)
\end{aligned}
$$

dimana :

$\boldsymbol{i}=$ intensitas; $B 1, B 2=$ brightness $; \frac{B 2}{B 1}=$ brightness relative

Gambar 3. Persamaan Duty cyles PMW Led Ikan

\section{HASIL DAN PEMBAHASAN}

Light emitting diode (LED) merupakan lampu paling hemat energi diantara jenis lampu lainnya, meskipun harganya relatif mahal. LED mempunyai energi (watt) yang sangat kecil hingga mampu menghemat listrik 1/5 dari biasanya. LED juga bisa bertahan sangat lama hingga 20 -an tahun. Sebagai perbandingan bahwa penggunaan LED dengan energi 3 watt setara dengan lampu pijar atau bohlam 20-an watt, selain itu juga lampu pijar jangka keawetannya belum dijamin dengan baik.

\section{Perancangan LED ikan}

Perancangan LED ikan penghasil cahaya bersumber pada LED (light emitting diode), sebagai alat yang dikategorikan atraktor buatan dan diintegrasikan dengan komponen elektronik. Faktor yang menentukan dalam pengoperasian terletak pada kombinasi LED ikan dipasangkan pada masing-masing kerangka muka LED. Alat ini mempunyai sistem pengaturan iluminasi terdiri dari rangkaian sistem mikrokontroler STEVAILL009V1 dan rangkaian driver LED menggunakan STP04CM596 (Gambar 4). Rangkaian driver LED digunakan untuk menyalakan kombinasi LED dengan pengaturan 
intensitas kecerahan dari LED diatur melalui nilai PWM. Semakin besar nilai PWM, maka nyala LED ikan akan semakin terang dan sebaliknya. Rekayasa LED ikan untuk mengumpulkan sekumpulan ikan mempunyai variasi panjang gelombang yaitu led putih $(600 \mathrm{~nm})$, biru (465-500 $\mathrm{nm})$, hijau $(500-520 \mathrm{~nm})$ dan amber $(595-605 \mathrm{~nm})$. Kisaran spektrum ini terwakili dengan warna cahaya biru sampai dengan warna cahaya merah. Rentang ini merupakan kisaran spektrum warna yang dikategorikan sebagai warna sinar tampak.

Tabel 1. Spesifikasi LED Ikan

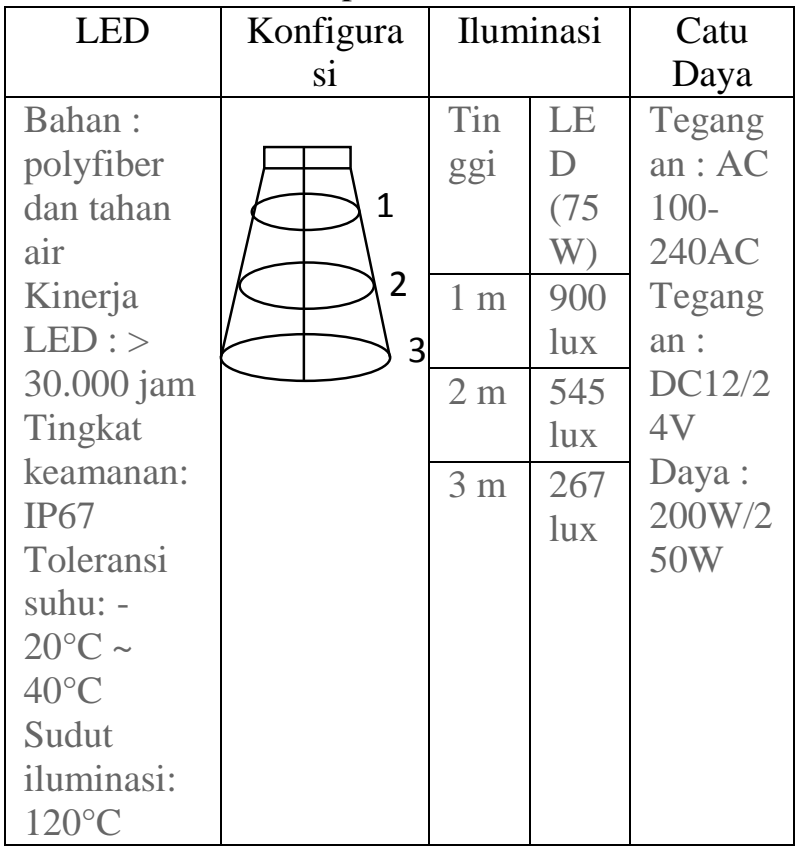

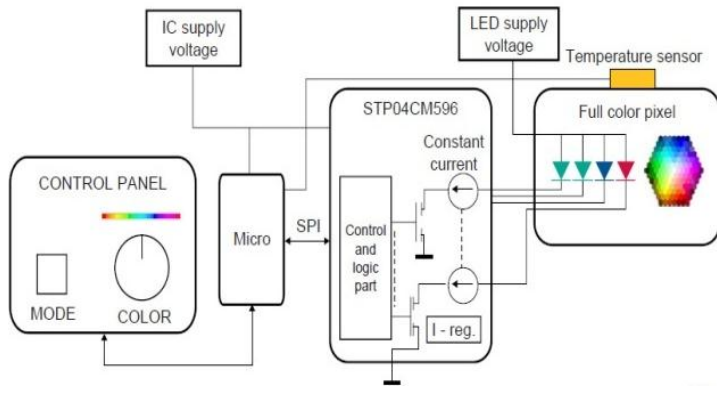

Gambar 4. Konfigurasi Sistem Kontrol LED Ikan
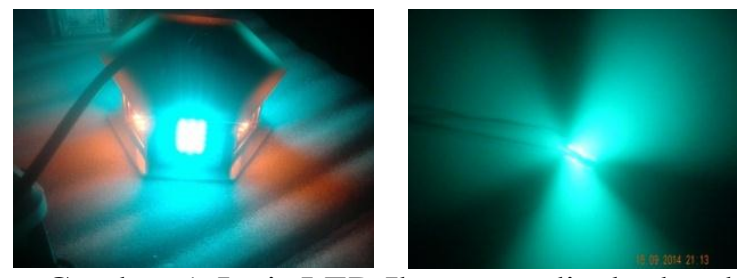

Gambar 5. Jenis LED Ikan yang dicelupkan ke dalam air laut

\section{Aplikasi duty cycle PWM}

Aplikasi PWM berbasis mikrokontroler berbasis dijital untuk mengatur nyala terang LED. Berbeda dengan PWM berbasis analog yang hanya mengandalkan pada sirkuit Op-amp. Pada metode dijital setiap perubahan PWM dipengaruhi oleh resolusi dari PWM itu sendiri. Menurut Widodo, B (2005) bahwa duty cycle $100 \%$ menginterpretasikan sinyal tegangan pengatur LED dilewatkan seluruhnya. Jika tegangan catu 12 Volt, maka LED akan mendapat tegangan $12 \mathrm{~V}$. Pada duty cycle $50 \%$, tegangan pada motor hanya akan diberikan $50 \%$ dari total tegangan yang ada, begitu seterusnya. Average voltage merupakan tegangan output pada motor yang dikontrol oleh sinyal PWM. a adalah nilai duty cycle saat kondisi sinyal "on", b adalah nilai duty cycle saat kondisi sinyal "off". V full adalah tegangan maximum pada referensi LED. Melalui perhitungan perbandingan di aplikasi duty cycle PWM dengan maka didapatkan tegangan output sesuai dengan sinyal kontrol PWM yang dibangkitkan. Jika tegangan yang dihasilkan adalah 50\% dari 24 VDC, maka diaplikasinya tercantum 12VDC. Untuk mengatur nilai duty ratio disini diperlukan suatu input yang nilainya adalah tegangan sebagai input data yang akan dibaca oleh sirkuit STP04CM596 dan nilai tersebut langsung dikonversikan menjadi 0-256 (nilai diskrit). Dari penjelasan sebelumnya bahwa duty ratio memiliki kisaran nilai antara 0-100. Oleh karena itu nilai yang ada pada STP04CM596 harus dikalibrasikan menjadi 0-100, dengan cara perhitungan aritmatika.

Pada Gambar 5 diperlihatkan contoh nilai PWM 8 bit berarti PWM tersebut memiliki resolusi $28=$ 256, maksudnya nilai keluaran PWM ini memiliki 256 variasi, variasinya mulai dari $0-255$ yang mewakili duty cycle $0-100 \%$ dari keluaran PWM tersebut. Sinyal PWM pada umumnya memiliki amplitudo dan frekuensi dasar yang tetap, namun memiliki lebar pulsa yang bervariasi. Lebar pulsa PWM berbanding lurus dengan amplitudo sinyal asli yang belum termodulasi (Romy, 2009). 
Artinya, Sinyal PWM memiliki frekuensi gelombang yang tetap namun duty cycle bervariasi (antara 0\% hingga 100\%).

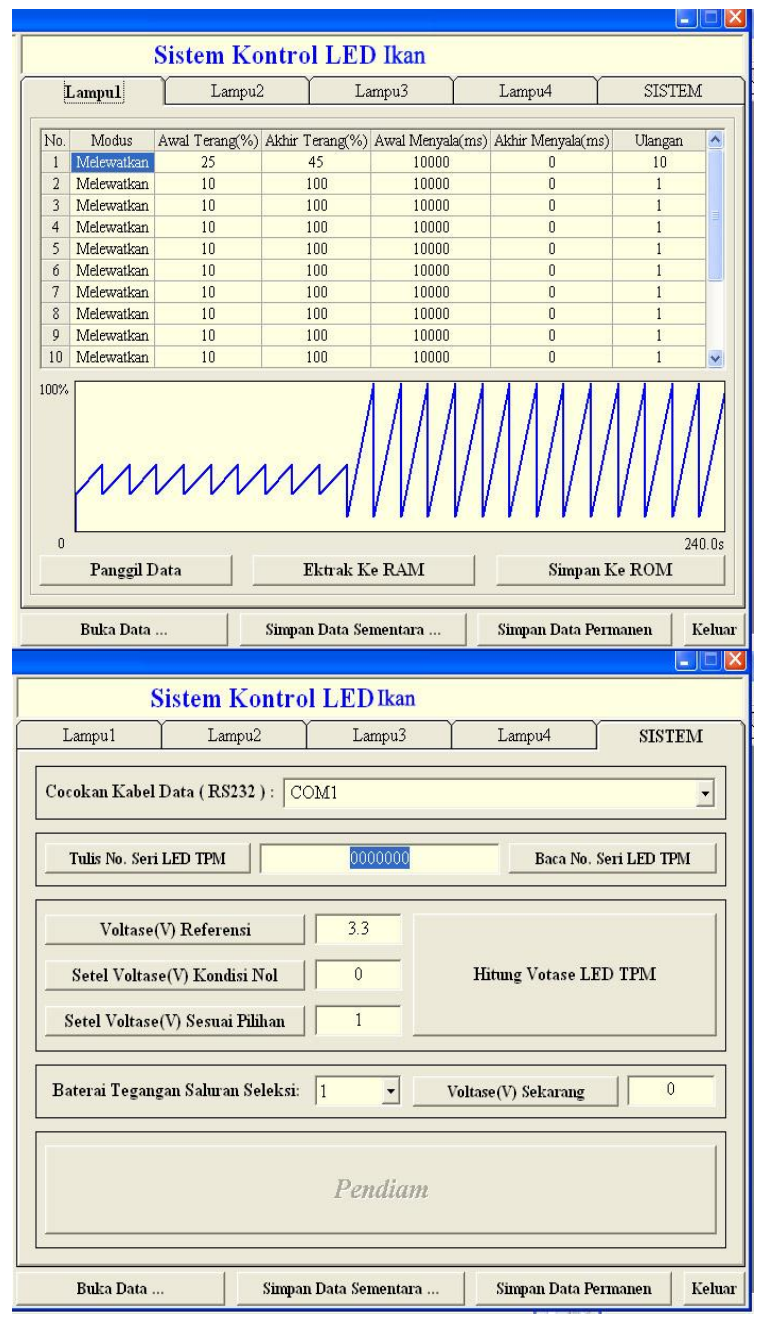

Gambar 6. Fitur duty cycle PWM

\section{Hasil pengujian alat}

Kemampuan fisiologis ikan untuk mendeteksi cahaya dari LED sangat tergantung pada indera penglihatan. Indera penglihatan ikan dapat membedakan gelap dan terang (brightness) suatu objek dengan cepat. Pada umumnya ikan-ikan pelagis kecil menyukai cahaya lampu pada rentang pita spektrum yang lebar. Kemampuan volume otak ikan tergantung kinerja kemampuan organ sensorik yang harmonis antara linea lateralis dengan otolith. Kedua organ ini memberikan stimulus pada otak untuk mengadaptasikan kemampuan fototaksis untuk mengenali obejek yang berpendar seperti plankton. Zooplankton yang terkena cahaya lampu akan mengalami proses perbendaran (scattered) dimana disekitar zona tersebut ikan-ikan pelagis kecil mengenalinya sebagai sumber makanan.

Untuk mengetahui pengaruh perbedaan besarnya intensitas cahaya LED ikan terhadap sekumpulan ikan yang mendekat ke alat tersebut, teridentifikasi ikan Stolephorus devisi dan Stolephorus indicus (Gambar 6). LED ikan dengan daya 200 watt mampu mengumpulkan ikan teri (Stolephorussp.) lebih banyak (Gambar 7). Hal ini menunjukkan bahwa tingginya nilai lumen dari kombinasi LED yang data-nya hasil input duty cycle mampu mengumpulkan jenis ikan lebih banyak ke sumber cahaya. Selain ikan teri yang berenang mendekati cahaya lumen LED, keberadaan ikan lain yang berada di kedalaman juga merespon cahaya LED. Hal ini dikarenakan bahwa LED yang mempunyai panjang gelombang lebih kecil mampu menembus hingga teridentifikasi pada kedalaman 30 meter yang divalidasi dengan benang pancing saat operasi LED ikan ini. Namun terdapat fenomena menarik dimana pada umumnya ikan selalu menjaga jarak dengan sumber cahaya. Berbeda halnya saat pengoperasiam LED ikan ini, sekumpulan ikan teri (Stolephorussp.) mendekati lebih toleran terhadap cahaya LED dengan dicirikan tingkah laku berenang tidak mengikuti pola renang searah jarum jam. Tingkah lakunya bergerak bolak-balok seiring pola duty cycle berbentuk menyerupai zig-zag dan cahaya LED tidak menimbulkan panas seperti halnya pada jenis lampu halide. Sekumpulan ikan teri (Stolephorus sp.) yang terus berkumpul di sekitar cahaya LED ikan bertambah lebih banyak, berdampak terhadap ikan-ikan pelagis yang mempunyai kemampuan fototaksis positif untuk datang. Selanjutnya ikanikan predator datang berkumpul di sekitar bagan. Meskipun ikan predator tidak tertarik pada cahaya, tetapi ikan mencari makan dengan tetap memanfaatkan indera penglihatan. 


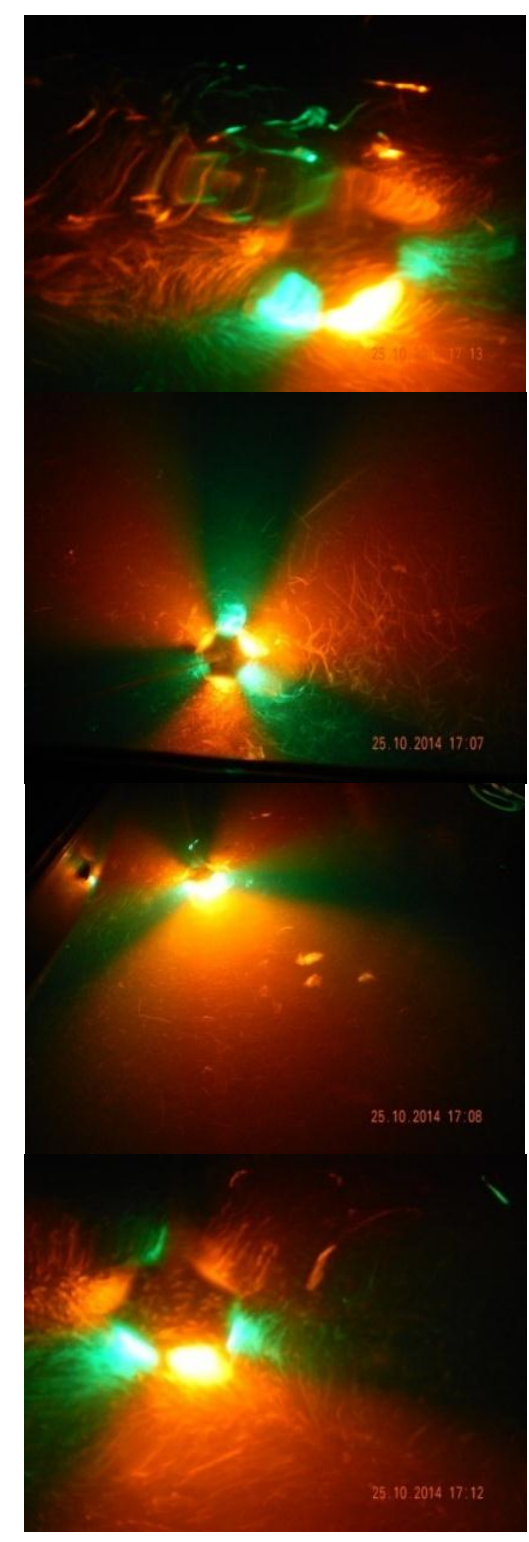

Gambar 7. Gerombolan Ikan Teri (Stoleporus sp.)

\section{KESIMPULAN DAN SARAN}

Mengatur nilai duty ratio pada pulse wave modulation (PWM) sebagai suatu input tegangan dibangkitkan melalui pembacaan di sirkuit STP04CM596 dan nilai tersebut langsung dikonversikan menjadi 0-256. Semakin besar nilai PWM, maka nyala LED ikan akan semakin terang dan sebaliknya. Rekayasa LED ikan untuk mengumpulkan sekumpulan ikan mempunyai variasi panjang gelombang yaitu led putih (600 $\mathrm{nm})$, biru $(465-500 \mathrm{~nm})$, hijau $(500-520 \mathrm{~nm})$ dan amber (595-605 nm).
Intensitas cahaya yang dihasilkan LED ikan berdaya 200 watt mampu menarik ikan teri (Stoleporus sp.) lebih banyak masuk dalam areal bagan beradaptasi secara sempurna. LED ikan tidak menimbulkan panas yang mengakibatkan ikan teri tidak menjauh dari batas toleransi yang berbeda-beda terhadap lumen LED. Tingkah laku ikan teri menunjukan bergerak bolak-balok seiring pola duty cycle berbentuk menyerupai zig-zag dan cahaya LED.

\section{UCAPAN TERIMA KASIH}

Kami mengucapkan terima kasih kepada Dinas Kelautan dan Perikanan, Kabupaten Wakatobi, Provinsi Sulawesi Tenggara atas kerjasamanya membantu dalam mensukseskan terciptanya uji coba LEDIKAN di bagan apung milik Dinas Kelautan dan Perikanan Kabupaten Wakatobi melalui proses diseminasi sampai ujicoba di laut bersama nelayan setempat. Tidak lupa kami juga mengucapkan terima kasih kepada para enumerator daerah yang telah mencatat dan memvalidasi hasil spektrum cahaya LEDIKAN untuk menarik perhatian sekumpulan ikan Teri (Stelaphorus sp.) di sekitar alat tangkap bagan apung sehingga keseluruhan uji cobanya sukses dilaksanakan.

\section{DAFTAR PUSTAKA}

Baskoro, M.S., R.I Wahyu, dan A. Effendy. 2004. Migrasi dan Distribusi Ikan. Institut Pertanian Bogor. Departemen Pendidikan Nasional dan Sekolah Tinggi Perikanan. Jakarta.

Guttsait , E.M. 2007. Analysis of LED modules for local illumination. J. Commun. Technol. Electron. 52: 1377 - 1395.

Guttsait E.M. 2009. Analysis of the illuminance provided by LED modules placed at large distances from illuminated objects, J. Commun. Technol. Electron. 54: 107 - 18.

Jeff, D. 1992. Assembly Language step by step. John Willey and Sons Inc. Canada.

Jeff, D. 2004. Design and Analysis of Hybrid Solar Lighting and Full Spectrum Solar Oak Ridge National Laboratory.

Jeff, D. 2003. Hybrid Solar Lighting Doubles the Efficiency and Affordability of Solar Energy in 
Commercial Building. Oak Ridge National Laboratory Newsletter.

Muhammd, A. M. 2000. The 8051 Microcontroller \& Embedded Systems Using assembly and $C$. Prentice-Hall Inc. New York.

Muhaimin. 2001. Teknologi Pencahayaan. Bandung. PT. Refika Aditama. Jakarta.

Najamuddin dan A. A. 1993. Studi Penggunaan Lampu Neon dalam Air dengan Daya yang Berbeda pada Perikanan Purse Seine di Laut Flores, Sulawesi Selatan. Buletin Torani. Makassar.

Nasution, M. F. 2010. Panduan Penggunaan Pulse Width Modulation. Universitas Petra Press,

Notanubun, J. 2010. Kajian Hasil Tangkapan Bagan Apung Dengan Penggunaan Intensitas Cahaya Lampu yang Berbeda di Perairan Selat Rosenberg Kabupaten Maluku Tenggara Kepulauan Kei. Tesis. Program Pascasarjana Universitas Sam Ratulangi-Manado.

Romy. W, B. 2009. Embedded System, Menggunakan Mikrokontroler dan Pemrograman C. Andi, Yogyakarta.

Usman. 2010. Teknik Antar Muka C+ Pemrograman Mikrokontroler STEVA-ILL009V1. Andi, Yogyakarta.

Widodo, B. 2005. Perancangan Sistem dan Aplikasi Mikrokontroller, PT. Elex Media Komputindo, Jakarta.

Yami. B. 1988. Attracting Fish with Light. FAO. Roma. 